\title{
Singapore, a Model for (Sustainable?) Urban Development in China
}

An Overview of 20 Years of Sino-Singaporean Cooperation

Rémi Curien

Translator. Jonathan Hall

\section{(2) OpenEdition}

\section{Journals}

\section{Electronic version}

URL: http://journals.openedition.org/chinaperspectives/7183

DOI: 10.4000/chinaperspectives.7183

ISSN: 1996-4617

\section{Publisher}

Centre d'étude français sur la Chine contemporaine

\section{Printed version}

Date of publication: 1 March 2017

Number of pages: $25-35$

ISSN: 2070-3449

\section{Electronic reference}

Rémi Curien, «Singapore, a Model for (Sustainable?) Urban Development in China », China Perspectives [Online], 2017/1 | 2017, Online since 01 March 2017, connection on 21 December 2020. URL : http:// journals.openedition.org/chinaperspectives/7183; DOI : https://doi.org/10.4000/chinaperspectives. 7183 


\title{
Singapore, a Model for (Sustainable?)
}

\section{Urban Development in China}

\author{
An Overview of 20 Years of Sino-Singaporean Cooperation
}

\author{
RÉMI CURIEN
}

\begin{abstract}
In order to face the challenge of sustainable urban development on its own territory, China has chosen Singapore as its model and privileged partner. By analysing more than 20 years of cooperation, the aim of this article is to study what sort of vision and model for development China is pursuing, how the "Singaporean model" is imported and incorporated by Chinese stakeholders, and in what ways it is transforming the specificities in planning, building, and organising the country's cities. Our analysis covers two Sino-Singaporean urban operations that are currently leading the way in China: the Suzhou Industrial Park and the Tianjin eco-city. The incorporation of the Singaporean model into these two operations shows that the latter offers an effective way of linking economic development with urban production, and of enabling the building of orderly cities with good environmental standards. However, these advances have only been made possible by the capacity to take political and financial initiatives that are still exceptional in the country as a whole, and until now do not appear to be easily extendable to other Chinese cities. Moreover, the Sino-Singaporean view of urban development based on productivity and concentrating on supply, infrastructure, and technology encounters major limitations in terms of environmental sobriety and the cities' social integration.
\end{abstract}

KEYWORDS: urban planning, eco-city, sustainable urban development, environment, models, infrastructure, technology, institutions, China, Singapore.

\section{Introduction}

S 1979 China has been undergoing rapid economic and urban development, with double-digit development up until 2013 and rapid large-scale urbanisation (200 million city residents rising to the present 700 million). This prodigious development has allowed it to become a major global power and to raise the living standards of a large part of its population. But it is also causing heavy damage to the environment, such as the effects of climate change, the scarcity and pollution of water sources, air pollution, and the over-use and pollution of land, and so on. This environmental degradation is giving rise to serious worries over both the availability and the sustainability of its natural resources, the health of the population, and even the long-term prospects for the Chinese economy.

In this context, after being heavily influenced by the Soviet model after 1949,(1) from the 1990s onwards the Chinese government has tried to experiment with new urban planning models, and since 2006 it has been officially engaged in an "environmental turnaround" with the stated ambition of switching to a developmental path requiring less use of resources and showing more concern for the environment. In the $12^{\text {th }}$ Five-Year Plan (2011-2015) it sets out national targets calling for a $16 \%$ reduction in energy use, and an increase in the share of nonfossil fuel in the overall mix by 2020 from $8 \%$ to $15 \%$; this directive has been continued under the $13^{\text {th }}$ Five-Year Plan. To achieve this goal, in 2008 it launched some ambitious economic programmes for circular economy and for "harmonious" urban development, mainly implemented on the ground through dozens of nationwide projects for eco-industrial parks and eco-cities.

Although China has pursued this objective by calling on expertise from many developed countries, particularly from the West (Germany, the United
States, France, Britain, Sweden, etc.), the most favoured country for bilateral cooperation is Singapore, which Beijing sees as a model for sustainable urban development. The two main urban operations considered to be at the cutting edge of national innovation are intergovernmental Sino-Singaporean projects: the Suzhou Industrial Park, launched in 1994, and the Sino-Singaporean eco-city of Tianjin, launched in 2007.

This article will analyse both of these projects, which represent two successive phases in Sino-Singaporean cooperation. (2) Through a diachronic analysis from the 1990s to the present we intend to see what vision and model for urban development is being followed by China, how the "Singaporean model" has been adopted and incorporated by Chinese stakeholders, and in what ways and to what extent it is transforming the actual modalities for planning, building, and running the nation's cities.

\section{The convergent interests of China and Singapore}

\section{Singapore, model of economic development}

1. Rémi Curien, "Chinese Urban Planning - Environmentalising a Hyper-Functionalist Machine?", China Perspectives, 2014/3, pp. 23-31

2. This analysis is based on surveys conducted on the spot between 2012 and 2014 (interviews with academics, administrative officials, industrialists, urban planners, and architects involved in these projects), combined with an overall analysis that was part of a doctoral thesis: Rémi Curien, Services essentiels en réseaux et fabrique urbaine en Chine: la quête d'une environnementalisation dans le cadre d'un développement accéléré - Enquêtes à Shanghai, Suzhou et Tianjin (Utilities networks and urban fabric in China: the quest for an environmentalisation in the context of an accelerated development - Investigations in Shanghai, Suzhou and Tianjin), University of ParisEst, 2014, pp. 452. The reader will find detailed references in this document. 
Beijing's choice of Singapore as model and privileged partner for urban development was primarily the outcome of an economic diagnosis. In 1979, the new Chinese leader Deng Xiaoping and his government took note of the poor state of the Chinese economy and the inefficiency of state enterprises. They identified the main causes as the lack of capital and expertise and the low level of technological development. To remedy these, they undertook reforms to open up the country: the introduction of market mechanisms and opening up to foreign capital, pro-urban policies, and liberalisation of the property market. (3) They opted particularly for the model based on Foreign Direct Investment (FDI) inspired especially by Singapore. Attracting foreign investment seemed to them the best way to inject capital, technology, and advanced management capabilities into the Chinese economy, thereby creating wealth and dynamism in the local economies, and developing the country.

Singapore was effectively an Asian pioneer in this field. ${ }^{(4)}$ Following its independence in 1965, the city-state chose the FDI-oriented development strategy, and the integration of foreign capital, technology, and developmental models. Its great success was shown by its rapid industrialisation and strong economic growth. This successful outcome was due to its choice of strong state intervention in the economy, such as the creation of national capital funds, the establishment of large public enterprises, the institutionalisation of savings on a national scale through income tax, and widespread reliance on immigrant labour. Within three years Singapore moved from being a Third World country to becoming a leading world economic power. Supported by this success story, it rose to the ranks of global models on two accounts: on its own account, Singapore saw itself and projected that view of itself as a model for Asian cities ${ }^{(5)}$ within its strategy for expanding foreign trade, but it was also a view shared by many Asian leaders.

\section{From the 1990s onwards Singapore has asserted itself as "urban model"}

Since the early 1990s, Singapore has built up its role as a model more particularly in the field of urban development and always in accordance with this dual process. From 1965 to the 1990s, development of the economy went hand-in-hand with the urban development of the city-state. Let us begin by considering above all Singapore's urban characteristics, which constitute the main aspects of its "urban model." Firstly, Singapore is a strictly controlled and regulated city. This is the result of its respect for and proper implementation of long-term urban development plans, thus avoiding the erratic urban transformations that can arise from changes in government. ${ }^{(6)}$ This stability and efficiency in urban planning are guaranteed by an authoritarian political regime and its specialised national agencies, such as the Housing and Development Board (HDB) for public housing, and the Jurong Town Corporation, which it created for industrial complexes. Secondly, Singapore offers a very dense mode of urban setting through the establishment of residential communities consisting largely of tower blocks. Thirdly, it combines industrial with urban development through the creation of "integrated industrial-residential communities" that enable the territory to become a support for economic growth, effectively combining economic and urban development. The high quality of the infrastructure and the essential utilities it provides (public roads, electricity, running water, gas, heating, cleaning, telecommunications) and of its urban setting enable foreign investment to be drawn in. This generates new jobs and a demand for housing and urban amenities, thus contributing to the financing of urban infrastructure and facilities. Fourthly, Singapore is known for its maturity and its technological innovations in the field of urban infrastructure - developed thanks to cooperation with industrialised countries - especially in the water supply sector (in its effort to limit its dependence on Malaysia for water, it has developed water recycling systems currently considered among the most advanced in the world). Fifthly, it offers a clean and pleasant physical urban setting, taking advantage of the abundant vegetation that has earnt it the name of "garden city." (7) But we should note that Singapore faces a severe limitation: its high energy consumption and its extreme reliance on a supply system dependent on fossil fuel.

The emergence of a "Singaporean urban model" in the early 1990s was at first a Singaporean initiative. As an entrepreneurial city-state, Singapore wanted to develop its external trade in order to overcome the economic limitations imposed by the smallness of its national area (720 square kilometres). Emboldened by its own success and full of self-confidence, it undertook to export its urban model to China and countries of Southeast Asia such as Indonesia (the Batamindo and Bintan projects) and Vietnam. ${ }^{\left({ }^{8}\right)}$ The Singaporean leadership set up international engineering and urban development companies as extensions of its national agencies, such as Surbana (a branch of HDB) and Jurong International (a subsidiary of Jurong Town Corporation). These national agencies and private companies sell their expertise on the market and offer the construction of urban industrial parks and residential complexes for export (at first mainly to Asia, then to the Middle East and Africa). The slogan displayed by Singapore at the 2010 Venice Architecture Biennale symbolised this long-term strategy: "1,000 Singapores" offered the image of the 6.5 billion inhabitants of the world spread across 1,000 islands resembling Singapore as a sustainable global model. (9)

\section{Singapore is Beijing's choice as a model and privileged partner for urban development}

The offer to supply on the part of Singapore met a demand on the Chinese side. In the post-Maoist situation, Chinese leaders were aiming at rapid economic growth, and in their view this had to take place through massive urban development, so Singapore was an extremely attractive proposition. Close in cultural terms (the population of Singapore is more than $70 \%$ ethnically Chinese) and socio-politically close to the Chinese regime (hegemonic rule by a single authoritarian party) Singapore is for Beijing a model of modernity and urban prestige compatible with the system in China. Singapore is also the foreign country most inclined to invest large sums in China's urban projects, probably because of the close cultural and socio-

3. For the emblematic case of Shanghai, see Dominique Lorrain, "Gouverner Shanghai: une modernisation publique," (Governing Shanghai: A public modernisation) in Dominique Lorrain (ed.), Métropoles XXL en pays émergents (The XXL metropolis in emerging nations), Paris, Presses de Sciences Po, 2011, pp. 53-138

4. Alexius A. Pereira, "The Suzhou Industrial Park Experiment:The Case of China-Singapore Governmental Collaboration," Journal of Contemporary China, Vol. 13, No. 38, 2004, pp. 173-193.

5. Chua Beng Huat, "Singapore as Model: Planning Innovations, Knowledge Experts," in Ananya Roy and Aihwa Ong (eds.), Worlding Cities: Asian Experiments and the Art of Being Global, Malden, Blackwell Publishing, 2011, pp. 29-54.

6. Ibid.

7. Puay Yok Tana et al., "Perspectives on Five Decades of the Urban Greening of Singapore," Cities, Vol. 32, 2013, pp. 24-32.

8. Martin Perry and Caroline York, "Singapore's Overseas Industrial Parks," Regional Studies, Vol. 34, No. 2, 2000, pp. 199-206.

9. Chua Beng Huat, "Singapore as Model: Planning, Innovations, Knowledge Experts," art. cit. 


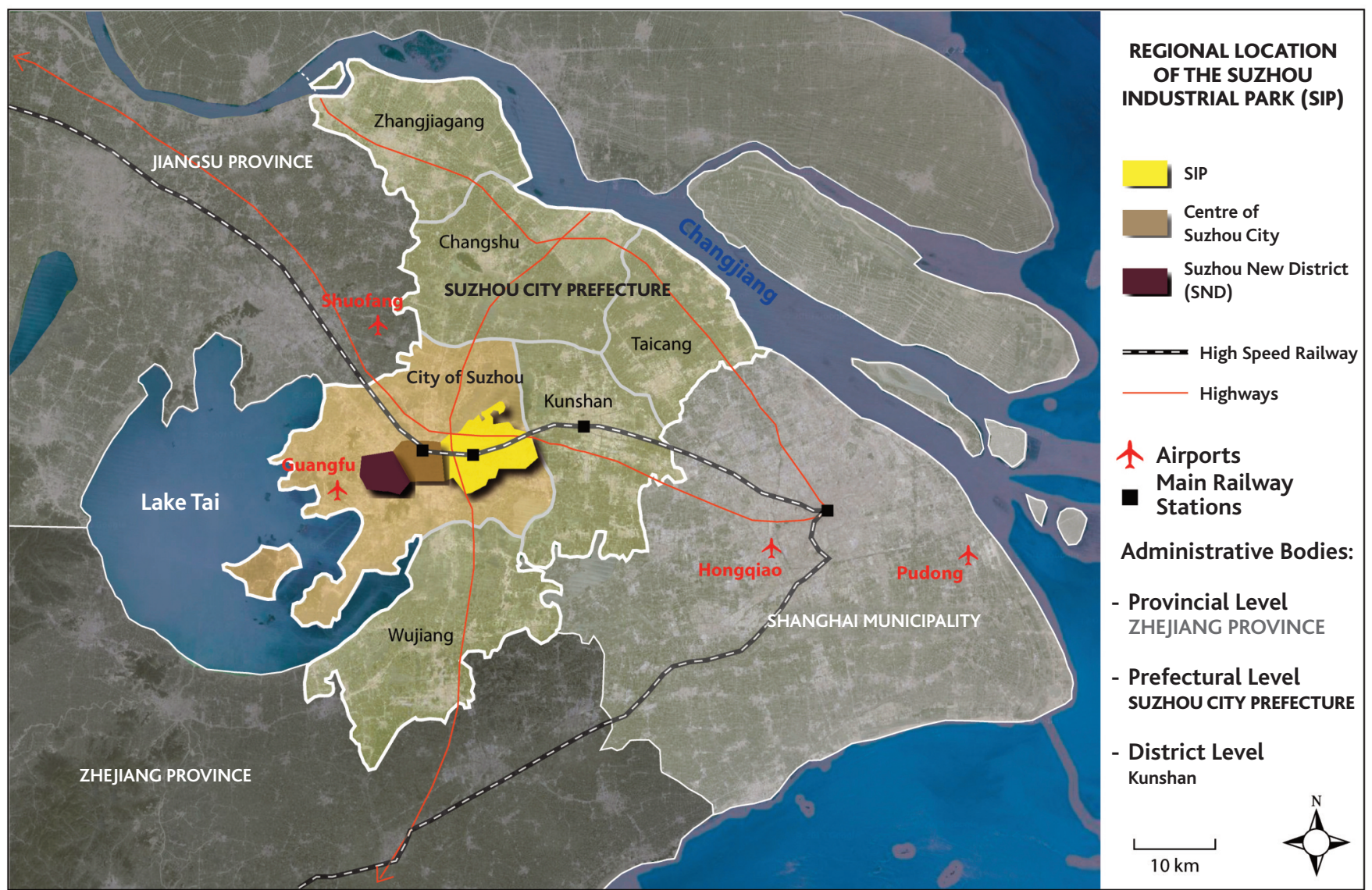

(c) R. Curien \& Safege, 2014.

political proximity of the two regimes. So the interests of Singapore and China converge.

The first collaborative projects in the urban sector by China and Singapore were initiated in the early 1990s. ${ }^{(10)}$ An intergovernmental programme for training local Chinese leaders and managers was started in 1992. From 1994 onwards, leaving aside the SIP (the pioneering Sino-Singaporean project to be discussed below), other projects were launched in China, especially in Dalian and Wuxi.

\section{Suzhou Industrial Park, the pioneering Sino- Singaporean project in China}

Initiated in 1994 and currently developed to $80 \%$ of the original plans, Suzhou Industrial Park has become both a gigantic industrial park and a no less gigantic new town, with 800,000 inhabitants and covering an area of 288 square kilometres. This project has required very strong Sino-Singaporean collaboration and colossal investment. The SIP is located in the middle of the prosperous Yangtze Delta on the axis linking Suzhou to Shanghai, and benefits from its strategic location adjoining the ancient city of Suzhou and in close proximity to Shanghai. With the opening of the high-speed rail link, it is 45 minutes from central Shanghai.

\section{An atypical and high-level Sino-Singaporean institutional steering}

The SIP is controlled by a strategic partnership between the governments of China and Singapore, represented by their respective presi- dents. Its political and financial organisation has been largely shaped by the Singaporean side, which makes it atypical. The project was established in two phases. Suzhou Industrial Park Administrative Co. (SIPAC) was set up by the Chinese State Council to establish the SIP's political authority, and was put in charge of planning and regulating the use of the land and natural resources, building works, and environmental protection. The SIPAC is under the direction of the representatives of the central government and of Suzhou, in association with representatives of Singapore. The special Sino-Singaporean agreement signed in 1994 provides for a programme of "transfer" of knowledge in every sector of its urban development and management. The other important institution is the company set up to provide the land management and infrastructure: China-Singapore Industrial Park Development (CSSD). This is a Sino-Singaporean joint venture company (initially $65 \%$ Singaporean and 35\% Chinese, but after 2001 these figures were inverted). The huge Singaporean consortium is controlled by the government of the city-state and includes several ministries and national agencies - such as the Urban Redevelopment Authority (URA), the National Environment Agency (NEA), and the Public Utilities Board (PUB) - as well as 24 large firms ${ }^{(11)}$ (led by Keppel Land, the energy company Singapore Technologies Industrial Corporation, and the developer Jurong Town Corporation). The Sino-Singaporean consortium has undertaken to invest the equivalent of 20 billion dollars over a period of 20

10. Pien Wang et al., "Establishing a Successful Sino-Foreign Equity Joint Venture: The Singapore Experience," Journal of World Business, Vol. 34, No. 3, 1999, pp. 287-305.

11. The Chinese consortium includes 12 major firms (notably the Bank of China, and Jiangsu International Trust and Investment). 


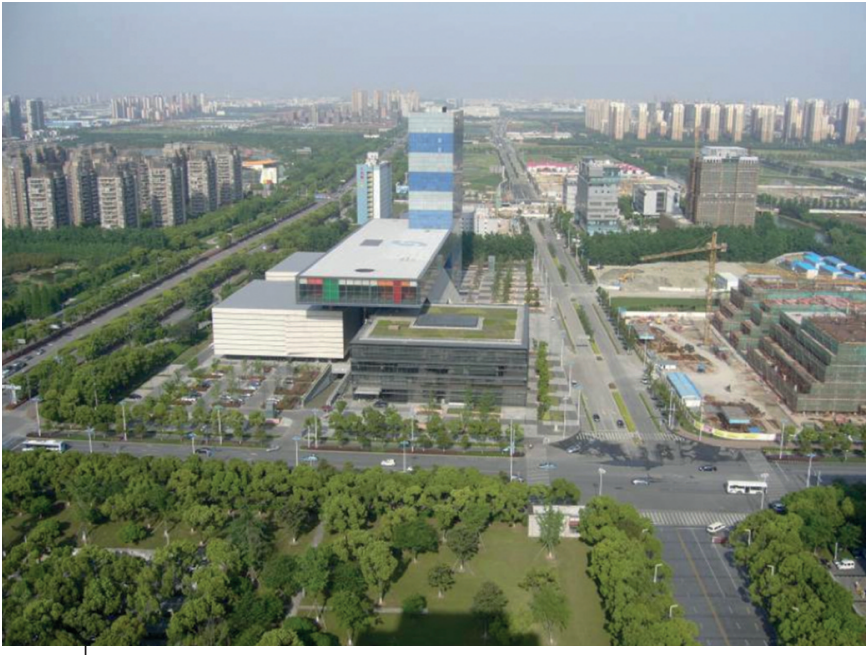

Photo 1 - Bird's-eye view of the SIP in 2012 @ R. Curien.

years. ${ }^{12)}$ The prime objective behind the Chinese and Singaporean joint effort in the SIP is to attract the maximum Foreign Direct Investment in order to stimulate Chinese local and national growth rates on the one hand, and generate direct profit returns on the other.

\section{$A$ vast integrated city-industrial park}

As in Singapore itself, the SIP initiated an integrated industrial and urban development. The first phase was planned in 1994 to be an area of 70 square kilometres. In 2001, when the Chinese became majority shareholders, the administrative area was expanded to $288 \mathrm{~km}^{2}$. Since the early $2000 \mathrm{~s}$ the SIP has undergone considerable development. At present the park includes nearly 10,000 enterprises, of which 4,000 are international. The main industrial production is in electronics, machinery, and pharmaceuticals, which are fairly light industries and less polluting than the other major ones in the country (petrochemicals, steel, etc.).

Nowadays the first thing to strike a visitor to the SIP is its urban character. There are so many residential blocks, office blocks, and commercial centres that at first sight one wonders where the factories and industrial activities are. Next one is struck by the urban layout:

- A large orthogonal road system forming a gigantic grid (two sets of two or three-lane highways with a total width of 50 to 60 metres), which bears a closer resemblance to motorways than to streets;

- An urban structural alignment of large rectangular blocks (several hundred metres wide) that are closed off (with only one or two entrances);

- An arrangement of urban functions split strictly into sectors. All the blocks are single-function, and there is a very clear separation of functions over the cityscape as a whole: there are industrial zones, residential zones, administrative zones, financial zones, commercial zones, and leisure zones.

The entire entity covers a huge area of $288 \mathrm{~km}^{2}$, that is to say, three times larger than the city of Paris. The above urban characteristics mean that it is almost impossible to move around without a car. Moreover, the previously sparse human habitation and the flat topography that characterises the place mean that it was possible to assemble this urban machine with a minimum of political, social, and physical friction. So at first sight the SIP seems to have nothing in common with an "ecological city," which would privilege compactness, mixed functionality, and less polluting means of transport.
By contrast, the SIP cultivates its own sophisticated brand image, with its refined skyline, its recent and impressive administrative centre enhanced by the location of its broad monumental square, and its remarkable cityscape with its perspectival display and related water features. This aesthetic concern is still rare in China's development zones. These attractions are reflected in the SIP's high property prices, which are close to those in central Shanghai.

In spite of the functionalism of this urban setting, the SIP has become a model of urban planning and environmental protection in China, as we will see.

\section{Emphasising infrastructure and utilities}

In the Singaporean model for "integrated industrial-residential communities" that has been applied to the SIP, the quality of the infrastructure and utilities plays a preponderant role in shaping the functional ensemble - effectively a machine for production - that fulfils the government's main goal of attracting foreign investment. The very name of this entity, "Suzhou Industrial Park," makes this logic explicit. The SIP is first of all an industrial park designed to attract FDI, and only secondarily is it a "city" that combines employment and residential accommodation: production takes primacy over living space. This fact explains why, apart from the establishment of advantageous financial arrangements, environmental concerns have been a major preoccupation from the outset on the part of the leadership. These concerns are considered decisive for economic competitiveness. Guaranteeing high-quality utilities to the companies and building an agreeable life setting for their employees and residents have been important elements in the strategy of creating an attractive brand image. This attention paid to environmental quality has taken two concrete forms (apart from the careful landscaping): on the one hand the building and maintenance of high-quality utilities, and on the other a system for controlling pollution that is likewise very sophisticated and strict regarding Chinese standards. (13)

The influence of the Singaporean model was preponderant in the choices of the SIP operational phasing. The first phase was the design and construction of the infrastructure for essential services. Once those were in place, the development moved on to industrial activities. Next came the residential buildings, and finally the installation of commercial activities. It must be stressed that this model demanded enormous basic investment, which was made possible by the exceptional political support of Singapore and China. The Singaporean consortium, in particular, very quickly built an electrical sub-station and a water treatment plant for the exclusive use of the park in order to guarantee the first tenant companies a constant supply of electricity and high-quality water for industrial use. Nowadays the SIP includes a drinking water plant, two wastewater plants, and one sludge treatment plant, three natural gas receiving-stations, and two co-generation plants. The investment, building, and management of the various systems of utilities are handled by a company founded in 1996 by the Sino-Singaporean consortium: CSPU (50\% affiliated with CSSD) under the authority of SIPAC's bureau for planning and construction.

12. Andrew C. Inkpen and Pien Wang, "An Examination of Collaboration and Knowledge Transfer: China-Singapore Suzhou Industrial Park," Journal of Management Studies, Vol. 43, No. 4, 2006, pp. 779-811.

13. These controls depend largely on the expertise of Singapore's Jurong Industrial Estate, which specialises in environmental pollution issues. See Tai-Chee Wong and Charles Goldblum, "The ChinaSingapore Industrial Park: A Turnkey Product of Singapore?", Geographical Review, Vol. 90, 2000, pp. 112-122. 
Since 2002, the SIP authorities have set up an even more ambitious environmental plan aimed at cutting back on the use of natural resources. They have caught onto the growing influence of the concept of a circular economy, and have begun to initiate or encourage the implementation of loops for reutilising materials, water, and energy among different activities. The SIP was recognised as a "circular economy pilot zone" in 2005, and then as an "eco-industrial national park" in 2008. But it should be emphasised that the SIP authorities do not set out precise figures for their targets in this respect.

At first the emphasis was on loops for exchanging resources in the electronics industries. The producers of semi-conductors, LCD screens, laptops, and mobile phones formed a primary local industrial chain for the exchange of materials, from the design phase to the production of circuits for computers, telephones, and television sets. ${ }^{(14)}$ However, according to our investigations on the spot, it remains difficult to assess their consistency. Moreover, it should be emphasised that they deal essentially with reutilising materials, not water or energy.

The park authorities have also encouraged companies to reuse their waste water for industrial purposes, but the amount of recycled water is still low. A major project is currently being handled by the CSPU in collaboration with Samsung, which owns one of the major factories in the park; its output is 24,000 cubic metres of waste water per year, of which half can be reused. The CSPU has just built an on-site treatment station for it and has plans to build three kilometres of pipes to supply neighbouring industrial units.

But the SIP's cutting-edge project in circular economy is the system set up between facilities at the southern extremity of the park:

- Two waste water treatment plants;

- A co-generating power station using two sources of combustion (natural gas and coal), which produces electricity to supply the regional grid and steam that supplies a local network;

- A sludge-drying facility operated by Sino-French SIP. (15)

In a conventional approach, the sludge ends up in a landfill site after being carried away by lorry, which entails the consumption of energy, $\mathrm{CO}_{2}$ emissions, and use of precious land in this densely populated region. Under these circumstances, the innovation consists of the achievement of a symbiosis - a circular relationship - between these facilities:

- The sludge is dried in the treatment plant using steam produced by the co-generating power station;

- The dried sludge is then used as fuel in the power station in the process of co-generation (it is burned together with coal);

- The co-generation power station reuses treated water for cooling;

- The ash produced by the power station is reused by a nearby cement factory, the product of which is used by the SIP.

In this way a synergy is set up, bringing a repurposing between the treatment of all the water used by the city-park and a part of the latter's energy production. This system, which was first set up in 2009 with the installation of the central link of the sludge-drying station, has been in operation since April 2011. According to Sino-French, it enables a reduction in $\mathrm{CO}_{2}$ equivalent to 44,000 tons per year (by saving 17,000 tons of carbon annually), as well as an annual savings of 3.8 million tons of water.

\section{A limited energy and environmental sobriety}

Nonetheless, the actual savings in relation to the overall consumption of the city-park remain low. Our quantitative analysis of the flows of water, materials, and energy set up by the systemic symbiosis shows that the repurposing derived from the dried sludge in the process of co-generation is indeed pertinent from the point of view of energy production (it enables more energy to be produced than is consumed in the process). But on the other hand, the quantitative contribution by sludge combustion to the SIP's overall energy production is very limited, amounting to $1 \%$ to $2 \%$. The synergy of sewage treatment and energy is real and pertinent, but its weight in the SIP's overall metabolism is still low. ${ }^{16)}$

Moreover, the resource exchanges take place within an extremely centralised technical system: the flows of input and output stretch over very large physical spaces (the entire $288 \mathrm{~km}^{2}$. of the SIP, and even beyond). In broader terms, the SIP has set up very few systems for reutilising resources and energy that would be real alternatives to conventional large networks: i) there is no system for collecting and reusing rainwater; ii) the reuse of waste water is very limited. There are abundant water resources in the region, so the pressure on them is not strong enough to weigh in the balance against the large cost required to build networks for reuse; iii) the share of local renewable energy in the overall energy mix is similarly low: there are only a few solar panels installed by some companies; iv) solid waste is also not recovered in energy or recycled within the SIP.

In short, the sewage treatment/energy synergy introduces a mere drop of symbiosis into the ocean of centralised, conventional, and heavy consumption of resources. The technical systems derive from their chosen point of departure and are fundamentally centralised, sectorised, and linear. This means that the solutions introduced in recent years, and aimed towards greater restraint, are merely tacked onto the margins of this conventional infrastructural frame. Moreover, if one widens the analysis beyond the utilities to cover the entire metabolism of the SIP (i.e., to include all the supplies of water, materials, and energy involved), and if one takes into account the figures related to transport activities (we have noted above the preponderant role of automobile traffic), it seems difficult to consider the SIP a model of sobriety.

\section{A model of environmental quality thanks to the Singaporean model}

If the goal of restrained use of resources seems distant, the SIP nonetheless has become a major reference for environmental quality in China. The quality of the distributed water is above the national average, and the loss rate is very low: a figure of $7 \%$ has been put forward, which is a good performance by international standards and remarkable for China. The SIP representatives also emphasise the high quality, by Chinese standards, of their treatment of waste water and sludge. The supplies of electricity and gas are reliable (very few outages). Natural gas, which is a less polluting source of energy than coal, represents a high proportion in the energy mixt.

This environmental quality is due to the Singaporean model, which depends on tried and tested principles. Firstly, the overall project is the out-

14. John A. Mathews and Hao Tan, "Progress toward a Circular Economy in China," Journal of Industrial Ecology, Vol. 15, No. 3, 2011, pp. 435-457.

15. JV co-founded by CSPU and Sino-French Water, which is itself a joint enterprise combining Suez and the Hong Kong developer New World.

16. Rémi Curien and Dominique Lorrain, "Suzhou Industrial Park: une reference environnementale dans un cadre productiviste" (Suzhou Industrial Park: an environmental reference in a productivist framework) in Dominique Lorrain et al. (ed.), Villes sobres (Low-carbon cities), Presses de Sciences Po, forthcoming in 2017. 
come of long-term planning intended to last at least 40 years. Secondly, the park aims at a high degree of territorial autonomy so as to achieve a "club effect" by sharply differentiating the site from the surrounding conditions. Indeed, the SIP was initially planned and equipped as an "island" within the megapolitan ocean of the Yangtze Delta, so the question of the provision of utilities was soon handled straightforwardly on the scale of the city-park. Thirdly, as we have seen, from the outset there was particular attention paid to massive investment in the infrastructure and utilities in order to attract FDIs. Fourthly, all the utility networks were immediately and simultaneously planned on the same scale to last for a minimum period of 40 years. ${ }^{(17)}$ The different networks were then built in a controlled and co-ordinated manner in accordance with established urban planning rules. Fifthly, the CSPU is in control of all the utilities (drinking water, sewage treatment, gas, electricity, heating) and plays a key role in integrating them all. This model enables all the companies to come together around a single table to co-ordinate the different networks. The maintenance of the latter is similarly facilitated and made more efficient. Sixthly, urban planning rules are respected and their stability maintained. Such control from planning to implementation is a major trait that contrasts with the usual urban operations in China. This outcome is due especially to the strict legal framework (unique in China) governing the collaboration of the Chinese and Singaporean parties, as well as the pressure exercised by the Singaporeans to ensure respect for the plans and control over the building works:

"In the SIP we have a legal management clause to ensure the application of the plans once they are agreed." (former leading SIP town planner, in interview).

"The Singaporeans keep closer to the norms [in comparison with the Chinese]; they are more serious." (CSPU official, in interview).

It can now be said that the intentions of 1994 have been fulfilled. Having assembled large amounts of Singaporean capital and expertise, although it did not manage to set up a completely accomplished model of environmental sobriety, the SIP is now considered in China to be a model not only for economic development but also for environmentally friendly urban construction in terms of the quality of infrastructure and utilities (especially the treatment of waste water and sludge) and respect for planning rules and control of construction.

\section{The second flagship project, the eco-city of Tianjin: A green city focused on technology and infrastructure}

In 2007, 13 years after the launch of the SIP and at a time when it was attracting a growing number of residents and companies, the governments of China and Singapore decided to launch a second showcase project: the Sino-Singaporean Tianjin Eco-City (SSTEC). Currently this is China's cuttingedge urban project. In comparison with the SIP, the SSTEC is more definitely oriented towards ecology: it was directly planned in pursuit of a goal of restraint on energy use and environmental protection, notably through its provision of technical systems for re-utilising resources under Singaporean influence. In this way its promotors intend it to become an exemplary project in environmental terms, which could in time be replicated throughout China.

\section{A far-reaching Sino-Singaporean partnership}

The Chinese government insisted on two criteria for choosing the location of this eco-city: the site should be on non-arable land (to satisfy the national priority for preserving agricultural land) and should be in an area of water scarcity. In the end a site in the municipality of Tianjin was selected, especially because of its strategic location: near Beijing and in the midst of a large urban area that forms the major economic pole of northern China. The exact site of the eco-city is 45 kilometres east of central Tianjin, in the Binhai development zone to the north of the TEDA (Tianjin Economic-technological Development Area).

The Tianjin Eco-City has a special administration similar to that of the SIP. At the very beginning of the project, the central government created an ad hoc administrative entity, Sino-Singapore Tianjin Eco-City Administrative Committee (SSTEC-AC), to oversee the launch and administrative management of the eco-city. The operation is controlled by a Joint Steering Council under the shared direction of the Chinese and Singaporean Vice-Premiers to decide its strategic aims, and by a Joint Working Committee under the Chinese Ministry for Urban Development and the Singaporean Ministry for National Development, while also including various government agencies to supervise the implementation of the project.

As in the case of the SIP, this Sino-Singaporean partnership provides for sharing expertise and experience between the administrations of both countries in the field of urban planning, environmental protection, resources conservation, water and waste management, and the preservation of "social harmony," by drawing on the following Singaporean agencies: URA, HDB, NEA, PUB, Building and Construction Authority (BCA), Land Transport Authority, and International Enterprise Singapore. These joint efforts have shaped the operational instruments that give this Chinese eco-city its distinctive character: the Key Performance Indicator (KPI) system, the overall urban Masterplan that likewise proclaims its innovative nature, the Green Building Evaluation Standards, the Integrated Water Management Guidelines, and so on.

In the SSTEC, the Chinese side is in charge of land acquisition and building the infrastructure, transport networks, and public buildings. A gigantic SinoSingaporean public-private joint venture was set up, with $50 \%$ of this consortium under the control of Tianjin TEDA Investment Holding and 50\% under the leadership of the Keppel Group. This joint venture is in charge of land development, real estate sales, economic promotion, and certain infrastructure. The capital provided by the Chinese side consists essentially of funds from the sale of land concessions, while that of the Singaporeans is from their financial investment. In the long term at least 30 billion yuan is to be injected into the overall operation.

\section{An innovative project aimed at environmental exemplarity}

Three organisations were involved in elaborating the overall urban planning of the eco-city: the Chinese Urban Planning Academy, the Tianjin Urban Planning Institute, and the Singaporean URA agency. This plan provided for building a city of 350,000 inhabitants and 210,000 jobs in an area of 34.2 $\mathrm{km}^{2}$, to be completed by 2020 , i.e., within only 12 years. The development

17. Shi Kuang et al., Xincheng guihui yu shijian: Suzhou Gongye Yuanqu lizheng (The planning and
implementation of a new city - the case of Suzhou Industrial Park), Zhongguo jianzhu gongye implementation of a new
chubanshe, 2011, pp. 293. 


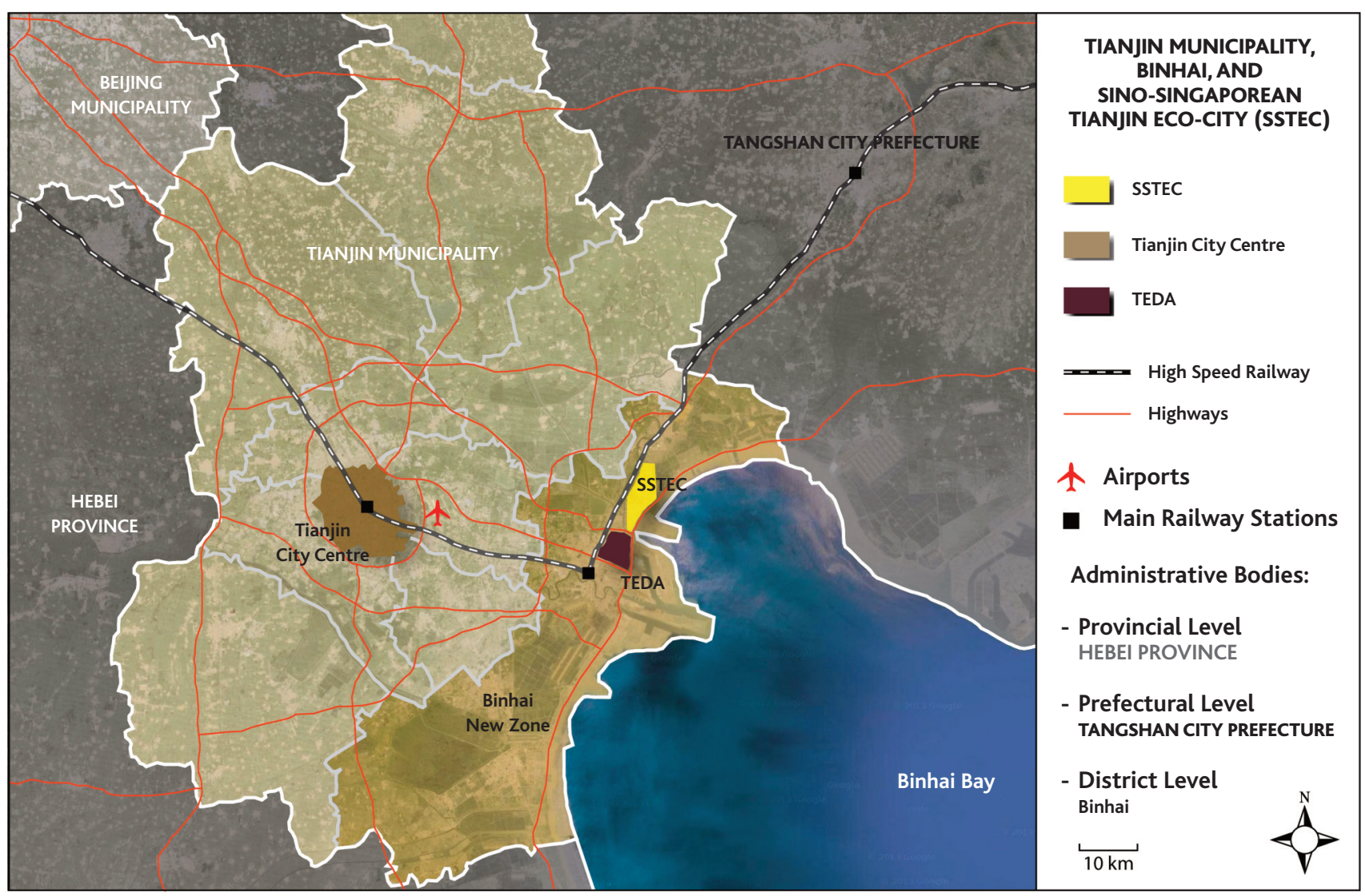

(c) R. Curien \& Safege, 2014.

was planned for three phases, the first two of which foresaw an initial settlement of 85,000 and the creation of 30,000 jobs in an area of $4 \mathrm{~km}^{2}$ on the southern boundary from 2008 to 2011 , to be followed by an increase to 200,000 inhabitants and 150,000 jobs with the provision of a future central zone between 2011 and 2015.

The project presents several original features, at least for China. Firstly, the eco-city is characterised by a predominance of residential function. The few industries for which there is provision are culturally creative, electronic, or eco-technological in the fields of solar energy, water, building, transport (electric vehicles), and waste, along with light industries that are neither heavy consumers of resources nor polluting, which contributes to the desired image of an innovative and attractive eco-city.

Secondly, as in Singapore, the urban Masterplan is intended to give a large space in the city to water and vegetation for many reasons (preserving soil quality and bio-diversity, recreational activities for the inhabitants, aesthetic values), by setting up and enhancing a lake, canals, a large central green space, and ecological corridors.

Thirdly, the SSTEC-AC has set high goals for itself in both environmental quality and sobriety through the reuse of grey water, pneumatic collection and recovery of solid waste, and the local production of renewable energy: solar, wind, and geothermal. The originality on paper for the SSTEC, in comparison with other Chinese eco-city projects, consists particularly of its system of quantitative indicators - Key Performance Indicators (KPI) - which was the outcome of a joint effort by Singaporean and Chinese experts organised by the SSTEC-AC to establish its precise aims and to ensure their achievement. This relies partly on China's national standards but often includes some more exacting indicators based on the Singaporean and other international models. There has been no other eco-city project in China that has established such exact indicators to control its implementation.

Fourthly, as with the SIP, the organisational arrangement allows for the co-ordinated and controlled design, construction, and exploitation of the different systems for essential services. The provision of all the utilities within the eco-city is in the hands of the same regulatory authority: the SSTEC-AC. The building and financing of the infrastructure is brought about by the same multi-sectoral company, Tianjin Eco-City Investment and Development, which is also a major shareholder of the companies providing the utilities.

Fifthly, several innovative technical systems are being set up.

Most of the energy is produced by two co-generating heat and power stations that preceded the launch of the project and are located outside its boundary. However the SSTEC authorities are making plans for some onsite production of renewable energy, which should in time provide $20 \%$ of the energy used in the eco-city, including geothermal sources for heating, solar power for heating water in the residential blocks and for street lighting, and wind power for generating electricity. Moreover, they have plans for restricting the demand for energy, which is largely determined by the building sector, by constructing green buildings for which they rely upon the Singaporean BCA agency (the target is for $100 \%$ of the buildings to be constructed according to these norms by 2020). A local system of heating and cooling to provide hot water and air-conditioning in a business park is also to be developed by Keppel Integrated Engineering.

This project stands out for the proposal to produce a high proportion (50\%) of its water supply from non-conventional sources such as desalinated seawater and reused waste- and rainwater, which would put it at the 


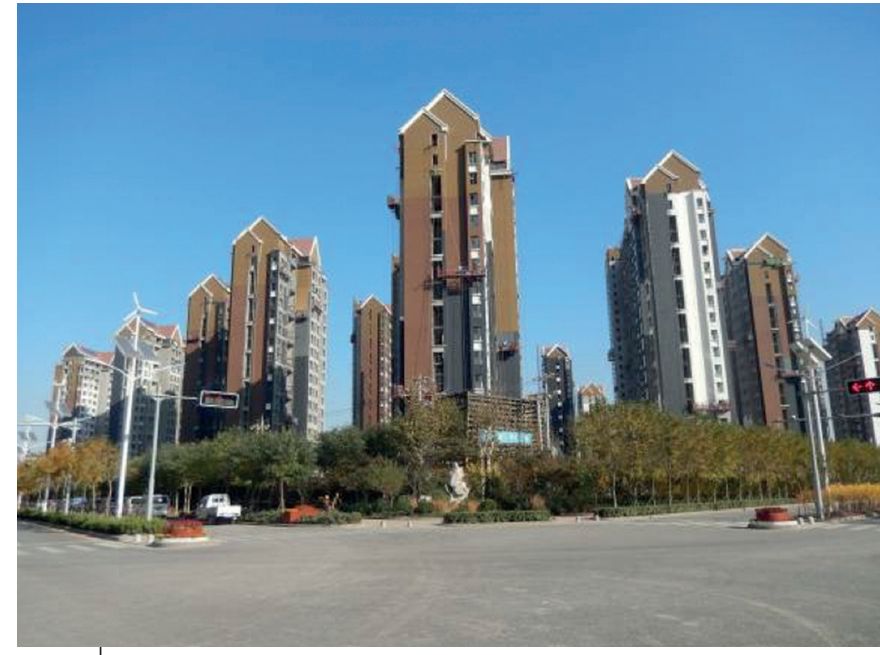

Photo 2 - The SSTEC Southern Zone ๑ R. Curien, November 2013.

level of Singapore, a world leader in this sector. This concern is a priority for the Chinese leadership. The SSTEC-AC has plans for the setting up of an autonomous centralised system for the collection, treatment, and reuse of waste water. In the long run all the used water from the city is to be piped into a treatment plant designed to achieve a capacity for handling $150,000 \mathrm{~m}^{3}$ per day, of which 105,000 would be for reuse. The water treated for reuse is to be piped to different locations and buildings in the eco-city for various purposes: flushing power, watering green spaces, road cleaning, refilling ponds and pools, etc. There are also plans for collecting rainwater. Two Singaporean agencies, NEA and PUB, have a major role to play in the design, building, and management of these water systems. The targets set by the SSTEC authorities are similarly high in the field of solid waste (recycling is set at $60 \%$ by 2013). In addition, there is a plan for a vacuum waste collection system.

\section{A city that is green and technologically eco-friendly, but still not very populated}

So far, $8 \mathrm{~km}^{2}$ has been built. Most of this is the southern residential zone, which consists of a series of orthogonal blocks separated by a grid of wide roadways. This zone is striking for the prominence of its greenery. The second striking feature of this cityscape is the visibility of the installations for producing renewable energy: the wind towers at the entrance to the SSTEC and the many solar panels along the roadways and on the roofs of the tower blocks. And finally, these areas are characterised above all by silence and the virtual absence of human beings, even though the city seems to have brought in more inhabitants since 2014: whereas there were between 2,000 and 3,000 inhabitants in November 2013, that number was put at around 20,000 in May 2015. (18) Be that as it may, if the physical setting has been completed more or less in accordance with the initial planning phase, by contrast the settlement of residents in the eco-city reveals a considerable delay. The responsible authorities are having great difficulty getting people to come and live there. Several experts interviewed in late 2013 even spoke of the eco-city as a "dead city" or a "ghost city."

There are several factors that might explain this lack of inhabitants, such as the excessively sustained rhythm of development, property speculation affecting the eco-city - several thousand apartments were bought by rich residents in Tianjin municipality but are currently unoccupied - the remote location of the SSTEC, and the continued lack of facilities and urban amenities (jobs, schools, hospitals, and commercial premises).

Concerning technical facilities, many solar panels and wind turbines, as well as geothermal units, have been installed in the southern zone, but it is difficult to know how many of them are in service yet. The running water system is built and is in service in the southern area. The networks for treating and reusing waste water have also been built. The waste water treatment station is built and has been in service since the end of 2012, but is not yet able to produce water for reuse. The vacuum waste collection system is already built and has been operational in the southern zone; it carries solid waste to a treatment station inside the SSTEC, which is then taken by lorry for handling outside the eco-city. However, several experts have informed us that the vacuum collection system is encountering major difficulties because of blockages in the tubes caused by residents' failure to sort solid waste materials properly.

\section{An incomplete urban project}

In more general terms, the technical innovations in place cannot be fully tested because of the insufficient number of residents. Apart from networks for essential services, a certain number of deficiencies are becoming apparent in the environmental quality and sobriety of the operation. In the first place, the follow-up to the implementation of the KPIs is conducted by the SSTEC itself and not by any external body, which reduces its credibility. Secondly, most of the land for the SSTEC was initially unsuitable for building, so the site preparation required artificial transformation of the soil itself and the importation of a considerable amount of earth from elsewhere. Thirdly, the environmental claims for the eco-city as a model for town planning seem questionable. Although the urban layout in the southern zone is indeed not hostile to the pedestrian, and although the urban metrics have more human dimensions than many new cities in China (including the SIP), this eco-city is still wedded to the form of a matrix of immense rectangular urban blocks (each one $400 \times 400$ metres), closed off and with only one or two entrances. This is inspired by the Singaporean "ecocell" concept, which posits these dimensions as the best possible basic urban unit for housing residents - it is a common feature in Chinese cities, and it makes moving about on foot very inconvenient. When interviewed, some urban specialists from the Tianjin Urban Planning Institute emphasised:

"The roadways are too wide. The size of each block is too big. Like Chang'an Avenue or Tiananmen Square in Beijing, they make the individual insignificant. The problem is that this metric is not ecological (chidu bu gou shengtai)." [translated from Chinese].

In sum, although the Tianjin eco-city offers a conception of the city and its utility systems that is in some respects innovative in China, there are lingering doubts about the implementation of the technical systems for reutilising resources, particularly because of significant delay in settling residents on the site. The fulfilment of the environmental goals seems to be compromised by deficiencies in urban planning and its material implementation: remote location, weak territorial integration, lack of amenities and public services, high levels of property speculation, and an urban model

18. Renmin ribao, 22 May 2015, http://j.news.163.com/docs/10/2015052214/AQ7R6NL8 90016NL9.html (accessed on 15 December 2016). 


\begin{tabular}{|c|c|c|}
\hline & Constant factors & Changing factors \\
\hline $\begin{array}{l}\text { From the SIP to the } \\
\text { SSTEC : the main } \\
\text { characteristics of } \\
\text { these Sino- } \\
\text { Singaporean urban } \\
\text { projects between } \\
1994 \text { and } 2016\end{array}$ & $\begin{array}{l}\text { Productivist approach, aimed at generating added financial value. } \\
\text { Strong governance and organised institutional integration. } \\
\text { Long term planning, stability, and respect for decisions taken. } \\
\text { High quality of infrastructure and essential services (water, energy, } \\
\text { waste); carefully tended physical amenities, abundant vegetation. } \\
\text { Functionalist large-scale urban model; an approach focused on } \\
\text { infrastructure and technology. }\end{array}$ & $\begin{array}{l}\text { Increased attention to environmental restraint, renewable } \\
\text { energy, and reutilisation of resources, including water and } \\
\text { biodiversity in the cities. } \\
\text { Priority given to the residential sector and higher added } \\
\text { value economic activities. } \\
\text { Better communication with the general public, especially } \\
\text { through the systematic display of performance indicators. }\end{array}$ \\
\hline
\end{tabular}

○ R. Curien \& Safege, 2016

and metric unsuitable for environmental goals. ${ }^{(19)}$ This case clearly shows the limits of the Sino-Singaporean approach focused on technology and infrastructure, which plays down other major aspects of a successful urban project: residents' expectations, ${ }^{(20)}$ amenities and public spaces, the integration of the project into its environment, and the coherence of the urban plan for the eco-city as a whole.

\section{From the SIP to the SSTEC, several ecological developments within a continuing focus on productivism}

A cross-reading of the SIP and the SSTEC enables us to bring out some major constants and some changes in this period of more than 20 years of Sino-Singaporean urban production in China. From 1994 to the present there has been a predominant constancy in the guiding principles behind these projects.

In the first place, the Chinese and Singaporeans are pursuing the same major objective in both the SSTEC and the SIP: beyond implementing a pilot project, it is a matter of generating capital gains. Their vision of the city and their approach to urban planning and development are above all productivist and functionalist. One EDF engineer in sustainable urban development stated his view in an interview with us that the Chinese and the Singaporeans share the same characteristic: their common aspiration to gigantism:

"The Singaporeans are not afraid of doing things on a big scale. They share with the Chinese the mind-set to say 'we go big'. This makes them different from the other countries going into China, which are often more cautious."

Secondly, the SIP and the SSTEC have the same modes of governance and institutional organisation. They are: bilateral leadership from the top; an ad hoc administrative structure directed at a central governmental level; equally shared financial investment and responsibilities through the creation of a Sino-Singaporean joint venture company; a regulatory authority responsible for all essential service networks and a multi-sectoral company in charge of their financing, construction, and maintenance, which enables co-ordinated and controlled planning, building, and operation of the different systems.

Thirdly, the Singaporean influence ensures long-term stable and respected urban planning. Fourthly, thanks to the two points mentioned above, the quality of the infrastructure and utilities set up - the idea being, apart from consequent environmental advantages, to achieve the greatest possible autonomy for the territory itself and to produce an effect of club membership because the differentiation of the site from its surroundings adds value to the project. The physical urban setting is likewise well cared for, being embellished by luxuriant vegetation.

Fifthly, the SSTEC, like the SIP, is based on an urban model and metric that remains functionalist: the urban layout consists of a rectangular matrix of huge boxed-in city blocks that are unsuitable for environmental objectives; in addition, the mixture of functions within each zone remains limited. Moreover, the approach to urban planning and development is still focused on the requirements of the infrastructure and technology.

Nonetheless the SSTEC operation displays several noteworthy developments in the outcome of Sino-Singaporean urban collaboration in China. The first of these is that there is greater attention to energy and environmental sobriety: for example, the local production of renewable energy (solar, wind, and geothermal), and the reuse of resources (waste water and solid waste). In addition, priority is given to the residential sector and to economic activities with greater added value and less pollution. Even greater care is taken with the quality of the urban living environment. Finally, there is greater effort given to communication with the public at large, especially through the open display of performance indicators.

\section{The advantages and limits of the penetration of the Singaporean model into Chinese cities}

The incorporation of the Singaporean model into these two cuttingedge projects in China shows that it provides an effective way of linking economic development with urban planning, and that it allows the construction of a more orderly and environmentally friendly quality than can generally be seen in new cities in China. The improved quality of the infrastructure and the utilities provided, of pollution treatment and energy

19. Rémi Curien, "'L'éco-cité de Tianjin : innovations et limites d'une conception sino-singapourienne d'une ville durable" (Tianjin eco-city: innovation and limits of a Sino-Singaporean conception of a sustainable city), Métropolitiques, 30 March 2016, http://www.metropolitiques.eu/L-eco-citede-Tianjin-innovations.html (accessed on 20 December 2016).

20. Andrew Flynn et al., "Eco-cities, Governance and Sustainable Lifestyles: The Case of the Sino-Singapore Tianjin Eco-City," Habitat International, Vol. 53, 2016, pp. 78-86. 
efficiency, and the care given to landscape and urban living environment quality, are all characteristic of the SIP and the SSTEC that have been fashioned by the collaboration with Singapore and now stand as models to be spread across the whole country by the Chinese government and its experts.

However, distributing the advantages of the Singaporean model among other Chinese cities is still limited, for two main reasons. Firstly, the "Singaporean model" is expensive: it requires colossal basic investment to build long-lasting, high-quality infrastructure, and this does not make it easily applicable to an ordinary new city in China. Secondly, in relation to the ordinary systems in China, it requires deep institutional changes in the way local administrations operate, and these have not yet been undertaken by Beijing. It effectively calls for long-term vision, continuity, and efficiency in the policies and plans being followed, and a close articulation between the different administrative bureaus involved, all of which are the opposite of the principles that currently guide local political and administrative practices, namely short-termism, great changeability in decisions already taken, and strong compartmentalisation of administrative bureaus.

Several of our interviews show how difficult it is to generalise the principle of stable and effective planning in Chinese cities. The work of urban planners usually carries little weight in the face of the overwhelming power of political leaders. One official from the planning and construction office for Suzhou City observed:

"In China we have an expression 'A plan drawn on a piece of paper is worth less than a sentence from the boss' [guihua zhishang huahua bu ru lingdao yi ju hua]. That means that planning depends on the good will of the local party leader. Another saying is 'One leader = one plan' [yi ren shuji, yi ren guihua], because the terms in office of city leaders are very short, usually three years, so one leader makes one plan and the next will probably overturn it all." [translated from the Chinese].

Another problem is the lack of overall planning and coordination between the administrative bureaus in the management of the different utility networks. As a result, the roadways are frequently dug up and turned into work sites. One commonly used expression, relayed to us by a professor from Tongji University, illustrates this phenomenon:

"In China we have an expression: 'making the road into a zip fastener' [zuo lalian malu]. One day you put in the gas pipes, and you close the zip opening; on the next day you open it again to put in the water pipes, and the same again for the telecommunications cables. It is a waste of effort, and the city is constantly turned into a succession of roadworks." [translated from the Chinese].

In sum, the advances in urban planning and environmental quality observed in the SIP and the SSTEC were made possible by political and financial capacities, legal arrangements, and organisational integration of the essential services that remain exceptional for the country and do not seem to be easily applicable throughout Chinese cities in general. The literature (21) and the experts in our interviews estimate that, apart from the SIP and the SSTEC, the environmental theme in projects named "eco-cities" or displayed as exemplary in China is above all a slogan. According to one urban expert from the Shanghai Engineering Institute:
"In China, these projects, apart from those co-managed with the Singaporeans, 'blow up the concepts' [chaozuo gainian], and do not pursue ecological goals. The eco-cities are 'packaging', estate agents' 'sales patter'." [translated from the Chinese].

Furthermore, even supposing that the financial and institutional conditions for diffusing the Singaporean model throughout Chinese cities could be brought together at some point in the future, it is still pertinent to question the validity of any wholesale generalisation of this model. In fact, SinoSingaporean urban production focused on supply, infrastructure, and technology has major limitations in terms of environmental sobriety and urban and social integration.

Our study shows that Chinese and Singaporean leaders continue to share an approach to urban production that is above all functionalist and productivist. Their projects give priority to the search for ways of generating added financial value, and make use of environmental messages within the logic of land marketing as a "passport" to modernity or urban prestige. They obtain positive results in terms of environmental quality and pollution treatment, but there is a patent gap between their proclaimed objectives and their materialisation in terms of sobriety in the uses of energy and natural resources. In the SIP and the SSTEC alike there is a technological and landscaping "ecological layer" added onto a very conventional urban planning and infrastructural framework that remains productivist, functionalist, centralised, and divided by sectors. There is an attempt at environmental friendliness, but it is marginal and complementary to the conventional urban and infrastructural structure. These entail an expensive use of natural resources and energy, and structurally block the development of resource reutilisation systems and a more substantial "environmentalisation." In addition, this "infra-techno-focused" approach pays insufficient attention to the expectations and behaviour of the residents who make use of it.

This model also leads to problems in coherence and urban and social integration: there is insufficient account taken of the territorial context, a tendency toward territorial isolation, (22) and marked inequalities in access to housing in view of its high costs. In the SSTEC there is a striking contrast between the highly-favoured social category of rich owners for whom most of the residences are built and the rudimentary social conditions of the underprivileged temporary migrant workers who build them. ${ }^{(23)}$ The case of the Tianjin eco-city shows that the success of such projects depends not only on technology but above all on urban social factors.

Looking beyond the Sino-Singaporean projects, our investigations on the spot in Tianjin, Shanghai, and Suzhou show that, in a manner similar to the SIP and the SSTEC, in Chinese cities there is a partial improvement in environmental quality to be seen, whereas sobriety in the use of resources remains a distant prospect. (24) Environmentalisation is restricted by being embedded in strongly developmentalist urban production. The national pri-

21. Choon Piew Pow and Harvey Neo, "Seeing Red Over Green: Contesting Urban Sustainabilities in China," Urban Studies, Vol. 50, 2013, p. 2256-2274; Chien Shiuh-Shen, "Chinese Eco-Cities: A Perspective of Land-Speculation-Oriented Local Entrepreneurialism," China Information, Vol. 27, 2013, pp. 173-196.

22. Tai-Chee Wong, "Eco-Cities in China: Pearls in the Sea of Degrading Urban Environments?", Ecocity Planning, 2011, pp. 131-150.

23. Federico Caprotti, "Critical Research on Eco-Cities? A walk Through the Sino-Singapore Tianjin Eco-City, China," Cities, Vol. 36, 2014, pp. 10-17.

24. Rémi Curien, "Services essentiels en réseaux et fabrique urbaine en Chine : verdir le développement accéléré ?" (Essential services network and fabrique urbaine in China: greening accelerated development?), Urbanités, special issue "Mondes urbains chinois," 2016, http://www.revue-urbanites.fr/services-essentiels-en-reseaux-et-fabrique-urbaine-en-chine-verdir-le-developpement-acce lere/ (accessed on 20 December 2016). 
ority for the next 15 years remains rapid large-scale development, with a target of 6-7\% economic growth. For the Chinese authorities, this must be achieved through massive urbanisation: a sustained urban growth rate of $4 \%$ per year, which amounts to an extra 300 million urban residents by 2030. To reach these objectives, the authorities maintain the arrangements set up since the 1980s: an entrepreneurial institutional system ${ }^{(25)}$ in which local political leaders are assessed by the Communist party-state essentially according to the economic growth generated in their constituencies over a short-term period; and a hyper-productivist and functionalist urban production operational mode. (26) Even today, in the eyes of Chinese leaders, what is modern is what is great: roads, buildings, facilities, networks, cities themselves. All these factors drag development towards the aims of productivism, short-termism, and patterns of standardisation, which is to say, in a direction fundamentally opposed to the requirements of environmental sobriety and sustainability.

\section{Translated by Jonathan Hall}

IRémi Curien is a geographer and urban planner with a doctorate in urban planning. He is a technical advisor on urban development in China at the French Ministry of Foreign Affairs and International Development (remi.curien@enpc.fr).

Manuscript received on 1 June 2016. Accepted on 7 December 2016.
25. Wu Fulong, "Re-orientation of the City Plan: Strategic Planning and Design Competition in China," Geoforum, No. 38, 2007, pp. 379-392; Zhang Tingwei, "Planning Theory and Reform in Transitional China," City Planning Review, Vol. 32, 2008, pp. 15-24.

26. Wu Zhiqiang et al., Chengshi guihua yuanli (Principles of urban planning), Tongji University, Zhongguo jianzhu gongye chubanshe, 2010 (4th edition); Rémi Curien, "Chinese Urban Planning - Environmentalising a Hyper-Functionalist Machine?", art. cit; Wu Fulong, Planning for Growth: Urban and Regional Planning in China, New York \& London, Routledge, 2015 